\title{
Reduced lipid intake leads to changes in digestive enzymes in the intestine but has minor effects on key enzymes of hepatic intermediary metabolism in rainbow trout (Oncorhynchus mykiss)
}

\author{
S. Ducasse-Cabanot ${ }^{1}$, J. Zambonino-Infante ${ }^{2}$, N. Richard ${ }^{1}$, F. Medale ${ }^{1}$, G. Corraze ${ }^{1}$, \\ M. Mambrini' ${ }^{3}$, J. Robin ${ }^{2}$, C. Cahu ${ }^{2}$, S. Kaushik ${ }^{1}$ and S. Panserat ${ }^{1 \dagger}$ \\ ${ }^{1}$ INRA, UMR1067 Nutrition Aquaculture \& Génomique, Pôle d'hydrobiologie, CD918, F-64310 St-Pée-sur-Nivelle, France; ${ }^{2}$ Ifremer, UMR1067 Nutrition Aquaculture \\ \& Génomique, Nutrition des Poissons Marins, Technopole Brest-Iroise BP70 29280 Plouzané, France; ${ }^{3}$ INRA, Laboratoire de Génétique des Poissons, 78350 \\ Jouy-en Josas, France
}

(Received 28 February 2007; Accepted 4 July 2007)

\begin{abstract}
For sustainable aquaculture, the removal of marine resource ingredients in fish diets is an important objective. While most studies focus on the replacement of fish oil by vegetable oil, little is known on the nutritional effects of presence (which corresponds to the control diet) or absence of dietary fish oil. We studied fatty acid composition of brush-border membranes and digestive enzyme activities of the intestine and measured the expression and activities of several enzymes involved in the hepatic intermediary metabolism of rainbow trout (Oncorhynchus mykiss) fed for 7 weeks with or without fish oil. The diets were pair-fed to ensure that fish fed either diet had comparable carbohydrate and protein intakes. Absence of fish oil significantly reduced growth rate, protein efficiency and plasma lipid components. Activities of intestinal digestive enzymes were significantly decreased in the anterior intestine in fish fed without fish oil. In liver, dietary fish oil removal did not affect the transcript levels or activities of the main enzymes involved in lipogenesis (fatty acid synthase) and fatty acid $\beta$-oxidation (3-hydroxyacyl-CoA dehydrogenase), glycolysis or amino acid oxidation. It lowered the expression of the genes coding for gluconeogenic enzymes (glucose-6-phosphatase and phosphoenolpyruvate carboxykinase), but their enzyme activities were not affected. The activities, but not gene expression of lipogenic enzymes, involved in NADPH and malonyl-CoA formation were also modified after fish oil removal as reflected by higher activities of isocitrate dehydrogenase/glucose-6-phosphate dehydrogenase and acetyl-COA carboxylase enzymes. Overall, our results indicate that the intestinal digestive capacity was strongly modified by dietary fish oil removal, while hepatic intermediary metabolism was only marginally affected, in fed rainbow trout.
\end{abstract}

Keywords: aquaculture, digestion, fish oil, metabolism, rainbow trout

\begin{abstract}
Introduction
Compound diets used for intensive fish farming still contain high levels of marine feedstuffs. This impairs the sustainability of fish production, while aquaculture should be a solution to the decrease in marine natural resources (Naylor et al., 2000; New and Wijkstroem, 2002). Diets for salmonids, for instance, include large amounts of fish oil, because the addition of dietary lipids has a sparing action on proteins (Sargent et al., 2002). Given that fish oil is a limited
\end{abstract}

\footnotetext{
${ }^{\dagger}$ E-mail: panserat@st-pee.inra.fr
}

natural resource (New and Wijkstroem, 2002), much effort is being devoted towards research on alternatives to fish oil in the diets of farmed fish.

Increasing dietary fish oil has a nitrogenous sparing effect and improves the quality of fish flesh for human consumption (Sargent et al., 2002). Flesh content of n-3 polyunsaturated fatty acids (PUFAs) reflects the dietary content of these fatty acids. Attention must be paid to conserving in fish flesh high levels of eicosapentaenoic acid (EPA; 20:5n-3) and docosahexaenoic acid (DHA; 22:6n-3), known to play an essential role in protection against cardiovascular risk, diabetes type 2 and neurodegenerative 
Effect of dietary fish oil removal in rainbow trout

disease in humans (Bourre, 2005; Ismail, 2005, Nettleton and Katz, 2005). The implications of replacing dietary fish oil by a mix of vegetable oils have been widely studied in fish in recent years. It does not have marked effects on growth but liver fatty acid metabolism as well as muscle n-3 PUFA contents are affected in Atlantic salmon (Salmo salar) (Torstensen et al., 2000; Bell et al., 2001 and 2002; Stubhaug et al., 2005). However, using a fish oil 'finishing diet' at the end of the experiment can partially restore the EPA and DHA levels in fish flesh (Bell et al., 2003 and 2004; Torstensen et al., 2005). This illustrates once again that the quality of the lipid depots is driven by the fatty acid composition of the diet. This effect may be directed through the modification of the intermediary metabolism. Indeed, it is well known that fatty acids such as EPA and DHA regulate hepatic gene expressions by controlling the activities or abundances of key transcription factors involved in the regulation of hepatic metabolic enzymes (Jump et al., 2005; Sampath and Ntambi, 2005). In studies dealing with the substitution of fish oil by other lipid sources, the effects of removing fish oil is confounded with the effects of adding a source with a different fatty acid profile on overall metabolism (Bell et al., 2001 and 2002; Jordal et al., 2005; Stubhaug et al., 2005). From a quantitative point of view, we ourselves have found that an increase in supply of dietary fish oil modified the activities and expressions of key enzymes of the glucose metabolism and led to less-efficient carbohydrate metabolism in rainbow trout (Oncorhynchus mykiss) (Panserat et al., 2002). Thus, it appears that the interaction between fish oil and intermediary metabolism must be better understood to provide the basis necessary for the successful replacement of fish oil in fish diets.

Thus, in the present study, we analysed the effects of the removal of dietary fish oil (residual fatty acids being supplied by fish meal) on two tissues: liver, as the centre of intermediary metabolism, and intestine, as the first organ in contact with nutrients. In order to keep constant the protein and carbohydrate ingestion, the animals were pairfed, a quite original strategy in fish. We measured several enzyme activities and gene expression for candidate proteins involved in hepatic intermediary metabolism. In order to assess the effects parallel to digestive capacity, we measured the evolution of the fatty acid composition of the brush-border membranes (BBMs) and the activity of selected enzymes.

\section{Material and methods}

\section{Fish and diets}

A 7-week growth study was undertaken with duplicate groups of juvenile rainbow trout (100 fish per tank; initial body weight $139 \mathrm{~g}$ ) reared in our experimental fish farm (INRA, Donzacq, France) at $18^{\circ} \mathrm{C}$ under natural photoperiod in spring. Two diets were formulated and manufactured in our experimental unit. Diet HL contained $15.5 \%$ fish oil (Table 1) and diet LL had no fish oil but had a higher level of fish meal (Table 1). Based on the analytical composition of
Table 1 Composition of the experimental diets

\begin{tabular}{|c|c|c|}
\hline & & \\
\hline & $\mathrm{HL}$ & $\mathrm{LL}$ \\
\hline Ingredients $(\%)^{\dagger}$ & & \\
\hline Fish meal 70 & 46.5 & 55 \\
\hline CPSP G & 20 & 24 \\
\hline Fish oil & 15.5 & 0 \\
\hline Binder & 1 & 1 \\
\hline Gelatinised starch & 15 & 18 \\
\hline Mineral pre-mix & 1 & 1 \\
\hline Vitamin pre-mix & 1 & 1 \\
\hline Analytical composition & & \\
\hline Dry matter (DM; \%) & 90 & 84 \\
\hline Crude protein (CP; \% DM) & 50 & 61 \\
\hline Crude lipid (\% DM) & 25 & 10 \\
\hline Gross energy (kJ/g DM) & 24 & 21 \\
\hline $\operatorname{Starch}^{\ddagger}(\% \mathrm{DM})$ & 14 & 17 \\
\hline Fatty acid composition ( $\%$ fatty acids & & \\
\hline$\sum$ Saturated & 30.6 & 36.4 \\
\hline$\Sigma$ Monounsaturated & 38.4 & 38.0 \\
\hline$\Sigma$ Polyunsaturated fatty acids $n-6$ & 4.6 & 4.5 \\
\hline$\Sigma$ Polyunsaturated fatty acids $n-3$ & 20.6 & 14.4 \\
\hline
\end{tabular}

Abbreviations are: $\mathrm{HL}$ : fish fed with fish oil; LL: fish fed without fish oil. ${ }^{\dagger}$ Fish meal (Sopropèche, Boulogne-sur-Mer, France); CPSP: soluble concentrate of fish protein 70 (Sopropèche, Boulogne-sur-Mer, France); Fish oil: Feedoil (North Sea fish oil, Sopropèche, Boulogne-sur-Mer, France); Binder: Alginate GF 150 (Louis Francois exploitation, Saint-Maur, France); Gelatinised starch Amidaine A 200 (Amylum Aquitaine, Bordeaux, France); Mineral mixture (g or $\mathrm{mg} / \mathrm{kg}$ diet): calcium carbonate $(40 \% \mathrm{Ca}), 2.15 \mathrm{~g}$; magnesium oxide $(60 \% \mathrm{Mg}), 1.24 \mathrm{~g}$; ferric citrate, $0.2 \mathrm{~g}$; potassium iodide $(75 \% \mathrm{l}), 0.4 \mathrm{mg}$; zinc sulphate $(36 \% \mathrm{Zn}), 0.4 \mathrm{~g}$; copper sulphate $(25 \% \mathrm{Cu}), 0.3 \mathrm{~g}$; manganese sulphate $(33 \% \mathrm{Mib}), 0.3 \mathrm{~g}$; dibasic calcium phosphate $(20 \% \mathrm{Ca}, 18 \% \mathrm{P}), 5 \mathrm{~g}$; cobalt sulphate, $2 \mathrm{mg}$; sodium selenite ( $30 \% \mathrm{Se}), 3 \mathrm{mg} ; \mathrm{KCl}, 0.9 \mathrm{~g} ; \mathrm{NaCl}, 0.4 \mathrm{~g}$ (UPAE (unité de préparation des aliments expérimentaux, Jouy, INRA, France)); Vitamin mixture (IU or $\mathrm{mg} / \mathrm{kg}$ diet): DL-a tocopherol acetate, $60 \mathrm{IU}$; sodium menadione bisulphate, $5 \mathrm{mg}$; retinyl acetate, $15000 \mathrm{IU}$; DL-cholecalciferol, $3000 \mathrm{IU}$; thiamin, $15 \mathrm{mg}$; riboflavin, $30 \mathrm{mg}$; pyridoxine, $15 \mathrm{mg} ; \mathrm{B} 12,0.05 \mathrm{mg}$; nicotinic acid, $175 \mathrm{mg}$; folic acid, $500 \mathrm{mg}$; inositol, $1000 \mathrm{mg}$; biotin, $2.5 \mathrm{mg}$; calcium panthotenate, $50 \mathrm{mg}$; choline chloride, $2000 \mathrm{mg}$ (UPAE (unité de préparation des aliments expérimentaux, Jouy, INRA, France)).

${ }^{\ddagger}$ Starch deduction $=100 \times($ energy $-(39.6 \times \%$ lipid $+23.2 \times \%$ protein $)) / 17.2$.

the diet, the ration for each group was determined to ensure the pair-feeding of the animals (Table 2). Fish were hand-fed twice a day at $1.50 \%$ and $1.27 \%$ of body weight per day for groups $\mathrm{HL}$ and $\mathrm{LL}$, respectively. Fish were group weighed by tanks each week, to adjust the rations.

\section{Tissue and blood sampling, and brush-border membranes isolation}

At the end of the growth trial, 12 fishes from each group were randomly sampled $8 \mathrm{~h}$ after the meal and sacrificed by a sharp blow on the head. This delay was chosen because we have previously shown that it corresponds to the post-prandial peak of nutrient absorption at this water temperature (Panserat et al., 2002). Gut contents of the sampled animals were systematically checked to make sure 
Table 2 Calculated feed intake after use of pair-feeding protocol for fish weighting $100 \mathrm{~g}$

\begin{tabular}{|c|c|c|}
\hline & \multicolumn{2}{|c|}{ Diets } \\
\hline & HL & LL \\
\hline Ration size (g/day per $100 \mathrm{~g}$ fish) & 1.5 & 1.27 \\
\hline \multicolumn{3}{|l|}{ Feed intake $^{\dagger}$ ( $\mathrm{g} /$ day per $100 \mathrm{~g}$ fish) } \\
\hline Protein & 0.75 & 0.77 \\
\hline Lipid & 0.37 & 0.13 \\
\hline Carbohydrate & 0.21 & 0.22 \\
\hline \multicolumn{3}{|l|}{ Fatty acid intake ${ }^{\ddagger}$ (g/day per $100 \mathrm{~g}$ fish) } \\
\hline$\sum$ Saturated & 0.11 & 0.05 \\
\hline$\Sigma$ Monounsaturated & 0.14 & 0.05 \\
\hline$\Sigma$ Polyunsaturated fatty acids $n-6$ & 0.02 & 0.006 \\
\hline$\sum$ Polyunsaturated fatty acids n-3 & 0.08 & 0.02 \\
\hline
\end{tabular}

Abbreviations are: HL: fish fed with fish oil; LL: fish fed without fish oil.

${ }^{\dagger}$ Feed intake: [analytical composition of diets in nutrient $(\%) \times$ daily ration size $(\mathrm{g})] / 100 \mathrm{~g}$ fish.

${ }^{\text {F}}$ Fatty acid intake: [analytical composition for each fatty acids (in \% of fatty acids) $\times$ analytical composition of diets in lipid $(\%) / 100 \times$ daily ration size (g) $] / 100 \mathrm{~g}$ fish.

that the fish sampled had consumed the diet. The liver was immediately dissected and weighed and the intestine was open and washed for remaining digesta in sterile ice-cold saline solution $(\mathrm{NaCl} 9 \%)$. Tissues were weighed and immediately frozen in liquid nitrogen and kept at $-80^{\circ} \mathrm{C}$ pending assays. Blood was removed from the caudal vein and centrifuged $(3000 \times \mathbf{g}, 5 \mathrm{~min})$, and the recovered plasma was immediately frozen and kept at $-20^{\circ} \mathrm{C}$ pending the analyses of glucose, free fatty acids and triacylglycerols.

A fraction of the liver samples was reserved for the analysis of gene expression; the remaining part was used for enzyme activity measurements. The BBMs were purified from the intestine (avoiding any contamination by perivisceral fat and pancreatic tissues from the caeca) prior to the enzyme assays. To this end, two samples of intestines were pooled, so that we constituted six replicates per tank. Intestines were homogenised in Tris-Mannitol buffer. Of this homogenate, $10 \%$ was kept for lipase assays and the rest was used for purifying the BBMs of the enterocytes using the method of Crane et al. (1979).

\section{Chemical composition}

Chemical composition of the diets. The two experimental diets were analysed using the following procedures: dry matter after drying at $105^{\circ} \mathrm{C}$ for $24 \mathrm{~h}$, starch by the glucoamylase glucose oxydase method (Thivend et al., 1972) and gross energy in an adiabatic bomb calorimeter (IKA, Heitersheim Gribheimer, Germany). Protein content $(N \times 6.25)$ was determined by the Kjeldahl method after acid digestion. Total liver lipids were determined by the method of Folch et al. (1957), after extraction by dichloromethane rather than chloroform. Fatty acid composition of diets was determined in the total lipid extract. Fatty acid methyl esters (FAME) were prepared by acid-catalyzed transmethylation of total lipids using boron trifluoride $\left(\mathrm{BF}_{3}\right)$ in methanol according to Shantha and Ackman (1990) and were separated using a Varian 3400 gas chromatograph. FAME were identified by comparison with known standard mixtures (Sigma, St Louis, MO, USA) and quantified.

Fatty acid composition of the brush-border membranes. Of the purified BBM, $80 \%$ was used for lipid extraction. This was performed using the micro-method described by Jones et al. (1992). FAME prepared from the lipidic extract of the BBM fraction were separated by gas chromatography, in an AutoSystem PerkinElmer (PerkinElmer, Waltham, MA, USA) with a flame ionisation detector, BPX 70 capillary column $(25 \mathrm{~m} \times 0.22 \mathrm{~mm}$ i.d. $\times 0.25 \mu \mathrm{m}$ film thickness), splitsplitless injector, with helium as the carrier gas. The injector and detector temperatures were, respectively, $220^{\circ} \mathrm{C}$ and $260^{\circ} \mathrm{C}$. Initial temperature of the oven was $50^{\circ} \mathrm{C}$, increasing to $180^{\circ} \mathrm{C}$ by increments of $15^{\circ} \mathrm{C} / \mathrm{min}$, maintained for $5 \mathrm{~min}$, and finally increased to $220^{\circ} \mathrm{C}$ by increments of $3^{\circ} \mathrm{C} / \mathrm{min}$.

\section{Plasma metabolites}

Plasma glucose concentration was determined using the glucose oxidase method in a Beckman glucose analyser (Beckman II; Beckman Instruments Inc., Brea, CA, USA). Plasma triacylglycerol levels were measured by colorimetric enzymatic assay using hepatic lipase (EC 3.1.1.3), glycerokinase (EC 2.7.1.30), glycerol-3-phosphate oxidase (EC 1.1.3.21) and peroxidase (EC 1.1.11) as enzymes (PAP 150 kit; Biomérieux, Marcy-l'étoile, France). Plasma fatty acid levels were measured by colorimetric enzymatic assay using acyl-CoA synthetase, acyl-CoA oxydase and peroxydase as enzymes (Wako Nefa C kit; Wako Chemicals GmbH, Neuss, Germany).

\section{Enzyme activities}

Enzyme activities were performed on frozen-thawed tissues. Enzyme activities were expressed per $\mathrm{mg}$ of protein. Protein concentration was determined according to Bradford (1976) using a protein assay kit (Bio-Rad, München, Germany) with bovine serum albumin as standard.

Measurement of activities of digestive enzymes in intestine We analysed the lipase-like enzymes, a non-specific lipase that can hydrolyse carboxyl ester bonds of acyl-glycerols and other minor dietary fats, including cholesterol esters. Its activity likely reflects the effective lipolytic capacity of the intestinal tract. The other enzymes were indicators of BBM functionality: aminopeptidase N (EC 3.4.11.2); $\gamma$-glutamyltranspeptidase (EC 2.3.2.2); alkaline phosphatase (EC 3.1.3.1) and maltase (EC 3.2.1.20). Enzymatic activities were assayed on $20 \%$ of the purified BBM fraction except for lipase-like activities, which were assayed directly with the homogenates following the method described by lijima et al. (1998). Aminopeptidase $\mathrm{N}, \gamma$-glutamyl-transpeptidase, maltase and alkaline phosphatase were assayed in purified BBM fractions, according to Maroux et al. (1973), Meister 
et al. (1981), Dahlqvist (1970) and Bessey et al. (1946), respectively.

\section{Measurement of activities for hepatic metabolic enzymes} Among the enzymes involved in lipogenesis and fatty acid metabolism, we selected fatty acid synthase (FAS, EC.2.3.1.48), acetyl-CoA carboxylase (ACC, EC6.4.1.2), 3hydroxyacyl-CoA dehydrogenase (HOAD, EC.1.1.1.35) known to be highly regulated by nutrients (Sul and Wang, 1998; Reddy and Hashimoto, 2001; Tong, 2005). We measured also activity and expression of glucose-6-phosphate dehydrogenase (G6PD, EC.1.1.1.49) and NADP-isocitrate dehydrogenase (ICDH-NADP, EC.1.1.1.42) because these $\mathrm{NADPH}$-productive enzymes are linked to lipid metabolism (Salati and Amir-Ahmady 2001, Koh et al., 2004). Measures of lipogenic FAS and G6PD activities were carried out as described by Richard et al. (2006). ACC activity was assayed using an isotopic method as previously described for rainbow trout (Rollin et al., 2003), where the activities of the two ACC isoforms, ACC $\alpha$ and $A C C \beta$, were probably measured together. HOAD enzyme activities were determined following the method by Kobayashi et al. (1996). ICDHNADP enzyme activities have been obtained by measuring NADP reduction at $340 \mathrm{~nm}$ after addition of $89.7 \mathrm{mmol} / \mathrm{l}$ TEA-HCl at $\mathrm{pH} 7.4,41 \mathrm{mmol} \mathrm{NaCl}, 0.34 \mathrm{mmol} / / \mathrm{NADP}$, $0.43 \mathrm{mmol} / \mathrm{l} \mathrm{MnSO}_{4}, 4.17 \mathrm{mmol} / \mathrm{l} \mathrm{DL}$-isocitrate in samples after sonication and centrifugation at $12000 \times \mathbf{g}$ (liver samples have been homogenised in a cold ice buffer: $20 \mathrm{mmol} . \mathrm{I} \mathrm{Tris}-\mathrm{HCl} \mathrm{pH} 7.4,250 \mathrm{mmol} / \mathrm{l}$ manitol, $2 \mathrm{mmol} / \mathrm{l}$ EDTA, $100 \mathrm{mmol} / / \mathrm{NaF}, 10 \mathrm{mmol} / \mathrm{l}$ mercaptoethanol, $0.5 \mathrm{mmol} / \mathrm{IPMSF}$ ). The glycolysis pathway was analysed through assaying glucokinase (GK, EC 2.7.1.2), 6-phosphofructokinase (6-PF1K, EC) and pyruvate kinase (PK, EC.2.7.1.40). We also measured the activities of glucose6-phosphatase (G6Pase, EC.3.1.3.9), fructose-1.6-biphosphatase (FBPase, EC.3.1.3.1.1) and phosphoenolpyruvate carboxykinase (PEPCK, EC.4.1.132), key regulators of the gluconeogenic pathway (Pilkis and Granner, 1992; Van Schaftingen and Gerin, 2002). Glycolytic (GK and PK) and gluconeogenic (G6Pase, FBPase and PEPCK) enzyme activities were measured as previously described (Kirchner et al., 2003b). Measures of 6-PFK1 activities have been performed following Meton et al. (1999) with aldolase, triosephosphate isomerase and glycerol-3-phosphate dehydrogenase as co-enzymes. Protein metabolism is also particular in fish because it is orientated towards the oxidation of dietary amino acids for energetic purposes (Cowey and Walton, 1989). We measured as described by Mambrini et al. (1998) the expression of the key enzyme of this pathway, glutamate dehydrogenase $(G D H, E C .1 .4 .1 .3)$, which has a higher activity in fish compared with mammals (Dabrowski and Guderley, 2002).

Gene expression analysis by real-time quantitative RT-PCR Total RNAs were extracted from rainbow trout liver or from the anterior intestinal segment using TRIzol ${ }^{\circledR}$ reagent
(Invitrogen, Carlsbad, CA, USA). A total of $1 \mu \mathrm{g}$ of total RNA was reverse transcribed to CDNA with the Superscript $^{\mathrm{TM}}$ III RNAse H Reverse Transcriptase kit (Invitrogen) using oligo dT primers. Gene expression levels were determined by real-time quantitative RT-PCR (q-PCR) using the iCycler iQ ${ }^{T M}$ (BIO-RAD, Hercules, CA, USA). Analyses were performed on $10 \mu \mathrm{l}$ of the RT reaction mixture using the $\mathrm{iQ}^{\mathrm{TM}}$ SYBR $^{\circledR}$ Green Supermix (BIO-RAD, Hercules, CA, USA). The total volume of the PCR reaction was $25 \mu$, containing $200 \mathrm{nmol} / \mathrm{l}$ of each primer. Primers were designed so that they are overlapping an intron if possible (Primer3 software; Whitehead Institute for Biomedical Research/MIT Center, Cambridge, MA, USA) using known sequences in nucleotide databases (Table 3). Database (Genbank, http://www.genome.ad.jp/htbin/www_bfind?dna today; National Institute of Agronomic Research (INRA) Sigenae http://ensembl-sigenae.jouy.inra.fr/; Tigr Gene Index; http://compbio.dfci.harvard.edu/tgi/) accession numbers for rainbow trout genes were: gb|AF135403|-Genbank (gk), gb|AF120150|-Genbank (g6pase), gb|AF333188|-Genbank (fbpase), gb|AF246149|-Genbank (m-peck), tcaa0001c.m. 06_5.1.om.4-Sigenae (fas), tcbk0010c.b.21_5.1.om.4-Sigenae (acc. highly similar to ACC irrespective of the isoform: $\alpha$ or $\beta)$, tcad0001a.i.15_3.1.om.4-Sigenae (hoad short chain), TC72180-Tigr (g6pd), 15072560.1.om.4-Sigenae (icdhnadp) and gb|AJ419571|-Genbank ( $g d h$ isoform 2). We measured the level of acc transcripts without discerning acc $\alpha$ and acc $\beta$ because the genes coding for the two isoform cDNAs are still not characterised at the molecular level in all the rainbow trout genomic resources we screened (Tigr, Unigene, Sigenae EST databases). GDH is encoded by a multigene family; because the expression of each gene is tissue specific, we chose to focus on the major transcript in the liver, gdh2, and used the primers specific for this transcript that are already designed (M. Mambrini, personal communication). The q-PCR amplified products were checked for specificity by sequencing.

Relative quantification of the target gene transcript was done using ef1 $\alpha$ gene expression as reference (Olsvik et al., 2005). Thermal cycling was initiated with the incubation at $95^{\circ} \mathrm{C}$ for $90 \mathrm{~s}$ for hotstart $\mathrm{iTaq}^{\mathrm{TM}}$ DNA polymerase activation. In all, 35 steps of PCR were performed, each one consisting of heating at $95^{\circ} \mathrm{C}$ for $20 \mathrm{~s}$ for denaturing, and at $59^{\circ} \mathrm{C}$ for $30 \mathrm{~s}$ for annealing and extension, except for $g d h 2$, for which the temperature was set at $60^{\circ} \mathrm{C}$. Following the final cycle of the $P C R$, melting curves were systematically monitored $\left(55^{\circ} \mathrm{C}\right.$ temperature gradient at $0.5^{\circ} \mathrm{C} / \mathrm{s}$ from $55^{\circ} \mathrm{C}$ to $94^{\circ} \mathrm{C}$ ) to ensure that only one fragment was amplified. Samples without reverse transcriptase and samples without RNAs were run for each reaction as negative controls.

\section{Data analysis}

Data are presented as means \pm standard deviation. Except for q-PCR data analysis, we analysed the different diets with an unpaired two-tailed Student's $t$-test (Statistical Packages for the Social Sciences, 1999). Relative quantification 
Ducasse-Cabanot, Zambonino-Infante, Richard, Medale, Corraze, Mambrini, Robin, Cahu, Kaushik and Panserat

Table 3 Sequence of the primer pairs used for real-time quantitative PCR determinations of the trasncript level for several rainbow trout genes

\begin{tabular}{|c|c|c|c|c|}
\hline Genes & Name (position ${ }^{\dagger}$ ) & $5^{\prime}-3^{\prime}$ Forward primer & Name (position*) & $5^{\prime}-3^{\prime}$ Reverse primer \\
\hline Glucokinase $(g k)$ & GK1 (E2/E3) & tgaaggatcagaggtgggtgat & GK2 (E4) & gaaggtgaaacccagaggaage \\
\hline \multirow[t]{2}{*}{ 6-Phosphofructokinase $(6-p f k 1)^{\ddagger}$} & 6PFK1 (E1) & (a) ggtggagatgcacaaggaa & 6PFK2 (E1/2) & (a) cttgatgttgtcccctccat \\
\hline & 6PFK3 (E4) & (b) ggcatcaccaacctgtgygt & 6PFK4 (E4) & (b) gtcrttrtcgatggagcccac \\
\hline Pyruvate kinase (pk) & PK1 (E10) & ccatcgtcgcggtaacaaga & PK (E10/E11) & gcccctggectttcctatgt \\
\hline Glucose-6-phosphatase (g6pase) & G6PAse1 (E4) & tgcccacttcccacacca & G6PASE2 (E5) & agcccacagcaaaggagag \\
\hline Fructose biphosphatase (fbpase) & FBPASE1 (E4/E5) & gctggacccttccatcgg & FBPASE2 (E6) & cgacataacgcccaccatagg \\
\hline $\begin{array}{l}\text { Mitochondrial phosphoenolpyruvate } \\
\text { carboxykinase (m-pepck) }\end{array}$ & PECK1 (5'UTR) & gttggtgctaaagggcacac & PEPCK2 (E1) & cccgtcttctgataagtccaa \\
\hline Fatty acid synthase (fas) & FAS1 (E36) & gagacctagtggaggctgtc & FAS2 (E37) & tcttgttgatggtgagctgt \\
\hline Acetyl-coA-carboxylase (acc) & ACC1 (E49) & tgagggcgttttcactatcc & ACC2 (E50/E51) & ctcgatctccctctccact \\
\hline $\begin{array}{l}\text { 3-Hydroxyacyl-CoA dehydrogenase } \\
\text { (hoad) }\end{array}$ & HOAD1 (E3/E4) & ggacaaagtggcaccagcac & HOAD2 (E4) & gggacggggttgaagaagtg \\
\hline $\begin{array}{l}\text { Glucose-6-phosphate dehydrogenase } \\
\text { (g6pd) }\end{array}$ & G6PD1 (E2/E3) & cactacctgggcaaggagat & G6PD2 (E3) & ttgctcatcatcttggcgta \\
\hline $\begin{array}{l}\text { NADP-isocitrate dehydrogenase } \\
\text { (icdh-NAPP) }\end{array}$ & ICDH1 (E7) & gacagcaccaacagggcaa & ICDH2 (E8) & aagccagcctcgatggtctc \\
\hline $\begin{array}{l}\text { Glutamate dehydrogenase type } 2 \\
\text { (gdh2) }\end{array}$ & GDH2-1 (E1) & atcaagccctgcaaccacgtcct & $\mathrm{GDH} 2-2 \mathrm{E} 2)$ & tcttcactgtaacggatccccccttt \\
\hline Elongation factor 1 alpha (ef1 $\alpha$ ) & EF1TS (E7/E8) & tcctcttggtcgtttcgctg & EF1TAS (3'UTR) & acccgagggacatcctgtg \\
\hline
\end{tabular}

${ }^{\dagger}$ Positioned following the corresponding (heterologous) zebrafish or mammalian gene sequences: exon $n(E n)$, exon boundaries $(E n / E n+1)$, or untranslated region (UTR) (http://www.ensembl.org/).

${ }^{\ddagger}$ Primer sequences were chosen either on (a) specific trout sequence highly similar to liver 6PFK1 isoform (5' UTR) (tcbk0069c.k.05_5.1.om.4 (Agenae EST name)) or (b) on conserved nucleotide sequences between liver 6-PFK1 in different animal species: Canis familiaris (Ensembl Gene ID ENSCAFG00000010846); Homo sapiens (Genbank: BC006422); Rattus norvegicus (genbank: BC061791) (using degenerated primers chose where $\mathrm{Y}=\mathrm{C} / \mathrm{T}$; $\mathrm{R}=\mathrm{G} / \mathrm{A}$ ).

of the target gene transcript with ef1 $\alpha$ reference gene transcript was made following the Pfaffl method with the Relative Expression Software tool (REST ${ }^{\circ}$ ) (Pfaffl et al., 2001 and 2002). This mathematical algorithm computes an expression ratio, based on q-PCR efficiency and the crossing point deviation of the unknown sample $v$. a control group: $R=$ $\left[\left(E_{\text {target gene }}\right)^{\Delta C \mathrm{~T}}\right.$ target gene (mean control - mean unknown sample) $] /$

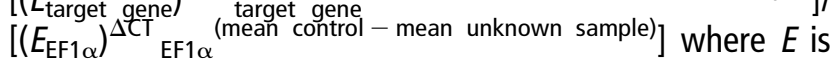
the PCR efficiency determined by a standard curve using the serial dilution of CDNA (CDNA dilutions from 1/16 up to $1 / 512$ ) ( $E$ has been accepted when $>90 \%$ ); $\Delta C T$ the crossing point deviation of an unknown sample $v$. a control. Statistical differences in gene expression between control and sample were evaluated in groups means by randomisation tests (Pfaffl et al., 2002) using REST ${ }^{\odot}$ software. In all, 2000 random allocations were performed. For all the statistical tests, significant differences were considered at $P<0.05$.

\section{Results}

During the growth study, mortality was low in all tanks and unrelated to experimental treatments and there were no external pathological signs. Fish consumed their ration entirely, so with pair-feeding, it was mainly the intake of lipids (such as PUFA n-3 fatty acid) that was different between the $\mathrm{HL}$ and LL fish (Table 2). Growth performance of juvenile rainbow trout fed with the $\mathrm{HL}$ diet was significantly higher than that of fish fed LL (Table 4; $P<0.01$, Student's $t$-test). The best protein efficiency ratio was observed in fish fed HL (Table 4; $P<0.05$, Student's $t$-test).
The liver weight and the hepatosomatic index were significantly higher in HL- than in LL-fed fish $(P<0.05$, Student's $t$-test). We observed that LL-fed fish had much lower mass of perivisceral fat tissue than $\mathrm{HL}$-fed fish (visual observation; data not shown). Glycaemia was not affected by the nature of the dietary treatment (Table 4). Plasma free fatty acid and triglyceride levels were higher in trout fed with $\mathrm{HL}$ than in those fed with the LL diet (Table 4; $P<0.01$, Student's $t$-test).

Reduction in the intake of lipids induced changes in intestinal digestive capacities (Table 5). Alkaline phosphatase, aminopeptidase $\mathrm{N}$ and $\gamma$-glutamyl peptidase-specific activities were significantly lower in LL fish than in $\mathrm{HL}$ fish $(P<0.05$, Student's $t$-test). The most important decrease in activity associated with fish oil removal was observed for lipase-like enzymes $(P<0.05$, Student's $t$-test). We did not notice significant effects on the fatty acid composition of the BBM (Table 5).

The removal of dietary fish oil did not affect the activity and expression of hepatic FAS and HOAD (Tables 6 and 7). ACC activity was three times higher in fish fed the LL diet compared with those fed the HL diet (Table 6, $P<0.01$, Student's $t$-test). In contrast, acc gene expression coding, irrespective of $\alpha$ or $\beta$ isoform, was not significantly different between $\mathrm{HL}$ and LL fish (Table 7). The activity of the cytosolic enzymes producing NADPH (G6PD and ICDHNADP) were 1.5 times higher in fish fed the LL diet compared with fish fed the HL diet (Table $6, P<0.05$, Student's $t$-test). By contrast, the expression of the genes coding for these enzymes was not affected by the dietary treatment (Table 7). Glycolytic enzyme activities and gene expressions 
Table 4 Effects of dietary lipid levels on growth performance, feed efficiency, liver and plasmatic parameters in juvenile rainbow trout over 7 weeks

\begin{tabular}{|c|c|c|c|}
\hline & \multicolumn{2}{|c|}{ Diets } & \multirow[b]{2}{*}{$P$-value ${ }^{\dagger}$} \\
\hline & $\mathrm{HL}$ & $\mathrm{LL}$ & \\
\hline \multicolumn{4}{|c|}{ Zootechnical parameters ( $n=2$ tanks with 100 fish per tank) ${ }^{\ddagger}$} \\
\hline Initial body weight (IBW) (g) & $139.50 \pm 0.50$ & $138.50 \pm 2.00$ & ns \\
\hline Final body weight (FBW) (g) & $236.03 \pm 3.28$ & $200.11 \pm 2.86$ & $P=0.01$ \\
\hline Daily growth index & $1.91 \pm 0.07$ & $1.30 \pm 0.01$ & $P<0.05$ \\
\hline Feed efficiency & $0.92 \pm 0.05$ & $0.77 \pm 0.02$ & ns \\
\hline Protein efficiency ratio & $1.86 \pm 0.10$ & $1.26 \pm 0.03$ & $P<0.05$ \\
\hline \multicolumn{4}{|l|}{ Liver parameters ( $n=12$ per diet) } \\
\hline Final liver weight $(\mathrm{g})$ & $4.19 \pm 0.81$ & $3.30 \pm 1.05$ & $P<0.05$ \\
\hline Hepato-somatic index ${ }^{\S}(\%)$ & $1.99 \pm 0.62$ & $1.63 \pm 0.28$ & $P<0.05$ \\
\hline \multicolumn{4}{|c|}{ Plasma parameters ${ }^{\top}(n=12$ per diet) } \\
\hline Glucose $(g / l)$ & $1.03 \pm 0.22$ & $0.95 \pm 0.16$ & ns \\
\hline Free fatty acids (mEq/l) & $0.14 \pm 0.05$ & $0.07 \pm 0.02$ & $P<0.001$ \\
\hline Triacylglycerols (g/l) & $9.77 \pm 5.99$ & $4.44 \pm 1.68$ & $P<0.01$ \\
\hline
\end{tabular}

Abbreviations are: HL: fish fed with fish oil; LL: fish fed without fish oil.

Data are expressed as means \pm standard deviation.

${ }^{\dagger} P$-values are shown when the differences are significant $(P<0.05$, Student's $t$-test); ns: not significant (Student's $t$-test, $P>0.05)$.

${ }^{*}$ Daily growth index: $100 \times\left(\mathrm{FBW}^{1 / 3}-\mathrm{IBW}^{1 / 3}\right) /$ duration (49 days). Feed efficiency: wet weight gain $(\mathrm{g}) / \mathrm{dry}$ feed intake $(\mathrm{g})$. Protein efficiency ratio: Wet weight gain $(\mathrm{g}) /$ crude protein intake $(\mathrm{g})$.

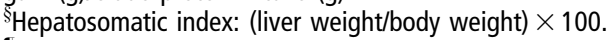

"Plasma parameters measured $8 \mathrm{~h}$ after feeding.

Table 5 Intestinal biochemical parameters measured $8 \mathrm{~h}$ after feeding between juvenile rainbow trout fed with a diet contained 15\% fish oils (HL) or not (LL). Enzymatic activities of digestive enzymes were expressed as $\mathrm{mU} / \mathrm{mg}$ protein. Data are expressed as means \pm standard deviation $(\mathrm{n}=6$ pools of two samples per diet)

\begin{tabular}{|c|c|c|c|}
\hline & \multicolumn{2}{|c|}{ Diets } & \multirow[b]{2}{*}{$P$-value ${ }^{\dagger}$} \\
\hline & $\mathrm{HL}$ & LL & \\
\hline \multirow{2}{*}{\multicolumn{4}{|c|}{$\begin{array}{l}\text { Enzymatic activities } \\
\text { Intestinal homogenate }\end{array}$}} \\
\hline & & & \\
\hline Lipase-like & $6.1 \pm 1.39$ & $2.8 \pm 0.39$ & $<0.01$ \\
\hline \multicolumn{4}{|l|}{ Brush border membranes } \\
\hline \multicolumn{4}{|l|}{ Digestive enzymes } \\
\hline Alkaline phosphatase & $2.3 \pm 0.34$ & $1.7 \pm 0.06$ & $<0.01$ \\
\hline Aminopeptidase & $1.8 \pm 0.16$ & $1.5 \pm 0.16$ & $<0.01$ \\
\hline$\gamma$-glutamyl transpeptidase & $244 \pm 17.4$ & $167 \pm 40.3$ & $<0.01$ \\
\hline Maltase & $222 \pm 20.5$ & $198 \pm 28.4$ & ns \\
\hline \multicolumn{4}{|c|}{ Fatty acid composition of brush border membranes ( $\%$ fatty acids) } \\
\hline$\sum$ Saturated & $31.6 \pm 0.9$ & $31.3 \pm 0.7$ & ns \\
\hline$\Sigma$ Monosaturated & $14.3 \pm 1.2$ & $17.0 \pm 1.7$ & ns \\
\hline$\Sigma$ Polyunsaturated fatty acids n- 6 & $2.1 \pm 0.1$ & $1.9 \pm 0.1$ & ns \\
\hline$\Sigma$ Polyunsaturated fatty acids $n-3$ & $35.3 \pm 1.8$ & $33.2 \pm 3.4$ & ns \\
\hline Including linolenic acid & $0.5 \pm 0.1$ & $0.4 \pm 0.1$ & ns \\
\hline Including EPA & $5.0 \pm 0.6$ & $3.6 \pm 03$ & ns \\
\hline Including DHA & $28.5 \pm 1.5$ & $28.2 \pm 3.3$ & ns \\
\hline
\end{tabular}

Abbreviations are: HL: fish fed with fish oil; LL: fish fed without fish oil; EPA: eicosapentaenoic acid; DHA: docosahexaenoic acid.

${ }^{+} P$-values are shown when the differences are significant $(P<0.05$, Student's $t$-test); ns: not significant $(P>0.05)$.

were not affected by the feeding regimes (Tables 6 and 7). In contrast, gluconeogenic enzymes were affected by the dietary treatment at both molecular and enzymatic levels: (i) transcripts of the first and last gluconeogenic enzymes (g6pase and mpepck) were significantly expressed at lower level in fish fed the $\mathrm{LL}$ diet compared with fish fed the $\mathrm{HL}$ 
Table 6 Enzymatic activities of proteins involved in hepatic intermediary metabolism $8 \mathrm{~h}$ after feeding. Specific enzymatic activities have been measured (mU/mg protein)

\begin{tabular}{|c|c|c|c|}
\hline & \multicolumn{2}{|c|}{ Diets } & \multirow[b]{2}{*}{$P$-value ${ }^{\dagger}$} \\
\hline & $\mathrm{HL}$ & $\mathrm{LL}$ & \\
\hline \multicolumn{4}{|l|}{ Lipid metabolism } \\
\hline Fatty acide synthase & $0.21 \pm 0.07$ & $0.26 \pm 0.04$ & ns \\
\hline 3-hydroxyacyl-CoA dehydrogenase & $122 \pm 23$ & $118 \pm 26$ & ns \\
\hline Acetyl-CoA-carboxylase ${ }^{\ddagger}$ & $0.44 \pm 0.06$ & $1.40 \pm 0.10$ & $P<0.01$ \\
\hline \multicolumn{4}{|l|}{ Glucose metabolism } \\
\hline \multicolumn{4}{|l|}{ Glycolysis } \\
\hline Glucokinase & $29.6 \pm 9.0$ & $31.3 \pm 12.8$ & ns \\
\hline 6-phosphofructokinase & $44.6 \pm 12.3$ & $51.3 \pm 10.8$ & ns \\
\hline Pyruvate kinase & $164 \pm 64$ & $137 \pm 80$ & ns \\
\hline \multicolumn{4}{|l|}{ Gluconeogenesis } \\
\hline Glucose-6-phosphatase & $26.1 \pm 1.2$ & $24.7 \pm 5.8$ & ns \\
\hline Fructose biphosphatase & $19.1 \pm 4.3$ & $26.8 \pm 3.8$ & $P<0.05$ \\
\hline Phosphoenolpyruvate carboxykinase ${ }^{\S}$ & $33.0 \pm 4.3$ & $29.6 \pm 3.8$ & ns \\
\hline \multicolumn{4}{|l|}{ Amino acid metabolism } \\
\hline Glutamate dehydrogenase & $153 \pm 16$ & $169 \pm 32$ & ns \\
\hline \multicolumn{4}{|l|}{ NADPH production } \\
\hline Glucose-6-phosphate dehydrogenase & $232 \pm 41$ & $342 \pm 66$ & $P<0.01$ \\
\hline NADP-isocitrate dehydrogenase & $108 \pm 14$ & $150 \pm 41$ & $P<0.05$ \\
\hline
\end{tabular}

Abbreviations are: $\mathrm{HL}$ : fish fed with fish oil; LL: fish fed without fish oil.

Data are expressed as means \pm standard deviation $(n=12)$ except for fatty acid synthase, Glucose-6-phosphate dehydrogenase, 3-hydroxyacyl-CoA dehydrogenase, Acetyl-CoA-carboxylase and NADP-isocitrate dehydrogenase $(n=6)$.

${ }^{\dagger} P$-values are shown when the differences are significant $(P<0.05$, Student's $t$-test); ns: not significant $(P>0.05$, Student's $t$-test).

${ }^{\ddagger}$ Total acetyl-coA-carboxylase (ACC) activity: ACC $\alpha+$ ACC $\beta$.

\$Total phosphoenolpyruvate carboxykinase (PEPCK) activity: mitochondrial PEPCK + cytosolic PEPCK. In trout liver, $90 \%$ of PEPCK activity is mitochondrial (Kirchner et al., 2003a).

diet (Table 7, $P<0.01$, Rest test) but without any modification of enzymatic activities (Table 6); and (ii) the FBPase enzyme had higher activity in fish fed the LL diet compared with fish on HL (Table 6 ; $t$-test, $P<0.05$ ) but fbpase gene expression was not affected by the dietary treatment (Table 7). Finally, the key enzyme involved in liver amino acid oxidation, the GDH enzyme, presented similar levels of molecular expression and enzymatic activity between the two dietary conditions (Tables 6 and 7).

\section{Discussion}

The main objective of our study was to evaluate the effects of dietary fish oil removal on the integrity of the digestive capacity and on liver intermediary metabolism in rainbow trout. We used a pair-feeding protocol in order to analyse the effect of dietary fish oil removal alone and not, as usually done, its replacement by vegetable oils (Bell et al., 2001 and 2002; Stubhaug et al., 2005). This strategy was rendered possible because the diet deficient in fish oil was based on fish meal containing on average $8 \%$ fat. This amount is sufficient to provide to rainbow trout the amount of essential fatty acids corresponding to the requirements
(National Research Council, 1993). With the pair-feeding technique, we succeeded in modifying the lipid intake of fish while maintaining the protein and carbohydrate supplies. This is shown by the plasma level of glucose, which was not affected by the dietary treatment, when plasma levels of free fatty acids and triglycerides were lower for fish fed the diet without added fish oil. The removal of fish oil led to an overall decrease in growth performance, feed and protein efficiencies as expected due to the lower level of total energy intake.

Fish oil removal in the diet had several effects at the digestive tract level: lipolytic activity was lowered by 2.2fold; activities of BBM digestive enzymes not linked to lipid metabolism were also greatly decreased (up to $40 \%$ ) in the LL group. This reveals that the enterocyte membrane has a lower digestive capacity if fish are fed diets with low lipids. This result was not the consequence of a modification in fatty acid composition of the enterocyte BBM and therefore of membrane fluidity, because this composition remained unchanged after 7 weeks of fish oil removal in the diet. Our results contrast with those obtained with European sea bass (Dicentrarchus labrax), where the activities of the digestive enzymes of the BBM were reduced and the fatty acid composition of the BBM was significantly modified 
Table 7 Real-time quantitative RT-PCR analyses of the transcript level of several genes expressed in the liver of trout juveniles fed a diet with no fish oil (LL) in comparison to a diet containing $15.5 \%$ fish oil (HL). Analyses were performed on samples taken $8 \mathrm{~h}$ after feeding. Statistical differences in gene expression level between $L L$ and $H L$ samples were evaluated in groups means by randomisation tests (Pfaffl et al., 2002) using REST ${ }^{\odot}$ software. A negative value of target genes was normalised with elongation factor 1 alpha (ef1 $\alpha$ ) expressed transcripts. For each diet, organs from 12 individuals were analysed independently

\begin{tabular}{|c|c|c|}
\hline Genes & $\begin{array}{l}n \text {-fold variation, } \\
\quad \mathrm{LL} v . \mathrm{HL}\end{array}$ & $P$-value ${ }^{\dagger}$ \\
\hline \multicolumn{3}{|l|}{ Lipid metabolism } \\
\hline Fatty acid synthase & +1.80 & ns \\
\hline 3-hydroxyacyl-CoA dehydrogenase & +1.08 & ns \\
\hline Acetyl-CoA-carboxylase & -1.48 & ns \\
\hline \multicolumn{3}{|l|}{ Glucose metabolism } \\
\hline \multicolumn{3}{|l|}{ Glycolysis } \\
\hline Glucokinase & +1.04 & ns \\
\hline 6-phosphofructokinase & $\mathrm{nd}^{\ddagger}$ & \\
\hline Pyruvate kinase & +1.62 & ns \\
\hline \multicolumn{3}{|l|}{ Gluconeogenesis } \\
\hline Glucose-6-phosphatase & -2.51 & $P=0.01$ \\
\hline Fructose biphosphatase & +1.42 & ns \\
\hline $\begin{array}{l}\text { Mitochondrial phosphoenolpyruvate } \\
\text { carboxykinase }\end{array}$ & -1.54 & $P<0.05$ \\
\hline \multicolumn{3}{|l|}{ Amino acid metabolism } \\
\hline Glutamate dehydrogenase type 2 & +1.16 & ns \\
\hline \multicolumn{3}{|l|}{ NADPH production } \\
\hline Glucose-6-phosphate dehydrogenase & +1.12 & ns \\
\hline NADP-isocitrate dehydrogenase & +1.07 & ns \\
\hline
\end{tabular}

Abbreviations are: HL: fish fed with fish oil; LL: fish fed without fish oil. ${ }^{\dagger}$ ns: not significant (randomisation tests REST ${ }^{\circ}, P>0.05$ ).

\#nd: non-detectable. Irrespective of the primers used in our assays (see Table 2), no successful amplification by RT-PCR for this gene has been obtained using hepatic total RNAs; the success was obtained only with total RNAs from muscle.

when the dietary lipid level was increased from $21 \%$ to $30 \%$ (Cahu et al., 2000). The fact that, in the present study, fatty acid composition of the enterocyte membranes was not affected by the dietary lipid level may be due to: (1) the lower lipid level of the control diet (HL diet) compared with the one employed in the study of Cahu et al. (2000), (2) the rigorous control of the nutrient intake in the present study and (3) a difference between species in the lipid metabolism, e.g. higher capacity to synthesise and metabolise fatty acid in the trout intestine. In general, PUFA synthesis in enterocytes could be increased in fish fed diets in which dietary fish oil was replaced with a vegetable oil blend (Tocher et al., 2003 and 2004) strengthened by the similar levels of EPA and DHA in BBMs observed in this study. Studies on lipid metabolism ( $\beta$-oxidation, biosynthesis) in the intestine are in progress. Overall, our data indicate that the digestive capacity was highly modulated in response to dietary fish oil removal.
It is well known that hepatic fatty acid metabolism is sensitive to regulation after feeding different quantities of dietary lipids in animals (Bergen and Mersmann, 2005). Moreover, previous studies have shown a close relationship between dietary lipids and hepatic lipid profiles in salmonids (Bell et al., 2001 and 2002; Tocher et al., 2001). In spite of this, no dietary effects at the molecular and enzymatic levels were observed in the present study for two key enzymes catalysing both the mitochondrial fatty acid $\beta$-oxidation (HOAD) and fatty acid biosynthesis (FAS). Concerning the absence of FAS regulation, our results are different from that found in mammals (Sampath and Ntambi, 2005) but in accordance with data obtained on rainbow trout fed diets with distinct (highly unsaturated) fatty acid profiles (Richard et al., 2006; Tapia-Salazar et al., 2006) or different levels of lipids (Henderson and Sargent, 1981; Gelineau et al., 2001): therefore, our data confirm the low control by dietary lipid intake of hepatic FAS enzyme in rainbow trout. The absence of HOAD regulation by lipid intake suggests an absence of regulation of the mitochondrial fatty acid $\beta$-oxidation but other key enzymes such as the carnitine palmitoyltransferase I, which mediates the transport of fatty acids across the outer mitochondrial membrane have to be further studied. In contrast to FAS and HOAD enzymes, ACC, G6PD and ICDH-NADPH enzymatic activities were significantly higher in fish fed the diet deprived of fish oil suggesting higher production of malonyl-CoA and NADPH in LL fish as has been described in mammals (Sampath and Ntambi, 2005) and rainbow trout (Rollin et al., 2003). Globally, the increase of G6PD, ICDHNADP and ACC activities did not seem to be dependent on the mRNA levels. Thus, only three of the five hepatic enzymes of lipid metabolism studied here responded to the fish oil removal and this regulation was not linked to concomitant differential gene expression in the present nutritional challenge.

Due to the intricate nature of glucose, amino acid and lipid metabolism in liver, we analysed also the enzymes involved in glucose and amino acid metabolism. Moreover, there are particularities of the protein and carbohydrate nutrition, i.e. protein metabolism in fish is mainly orientated towards the oxidation of dietary amino acids for energetic purposes (Cowey and Walton, 1989) and dietary glucose is poorly used at the metabolic level (Hemre et al., 2002). While there were no effects at the molecular and enzymatic levels for glycolytic enzymes (GK, 6PFK1 and PK) and for the key enzyme of amino acid oxidation (GDH), the expression of genes coding for key enzymes of the gluconeogenic pathway, g6pase and pepck were significantly modified. These genes are expressed at a high level in liver of carnivorous fish and are poorly controlled by dietary carbohydrates and fasted-fed status in rainbow trout (Panserat et al., 2000, 2001a and b). Their expressions were significantly reduced by the removal of fish oil in the present study. Our results confirm our previous finding in rainbow trout (Panserat et al., 2002) and are in agreement with data obtained in mammals (Lam et al., 2003; Collins 
et al., 2006). Our data suggest that the usual level of dietary fish oil in fish nutrition may be associated with the stimulation of the gluconeogenesis pathway, which at least partly explains the low metabolic dietary glucose utilisation in this carnivorous fish species (Hemre et al., 2002). Intriguingly, we found higher FBPase activities (another gluconeogenic key enzyme) in fish fed the LL diet in contrast to the lower gluconeogenic g6pase and pepck gene expression observed in the same fish group. At present, we have no explanation for the apparent discordant regulation by dietary fish oil of the three gluconeogenic key enzymes in our study.

We succeeded to disconnect lipid supply to carbohydrate and protein supply with pair-feeding. However, our results are linked to three major intricate factors: the lowering of the overall energy (e.g. lipid) supply, the proper effect of fatty acid reduction and the restriction of intake of fish fed the LL diet. Because dietary and, in particular, lipid restriction extends the life spans, studies of the biological mechanism behind dietary restriction are of interest in many species (Han and Hickey, 2005). In rat liver, dietary restriction results in up-regulation of gluconeogenic g6pase and pepck gene expression and a reduction of glycolytic $(g k, p k), a c c \alpha$ and icdh-nadp gene expressions (Dhabbi et al., 1999; Spinder, 2001). These variations of gene expression were not observed in the trout fed diet $\mathrm{LL}$, suggesting that our data were more related to the dietary fish oil removal per se than a lowering of energy intake. Moreover, we cannot determine which fatty acids were linked to the observed data because every fatty acid intake was more or less modified. Further studies using oral administration of fish oil/fatty acids (capsules filled with fish oil/fatty acids) or cell cultures will be necessary to delimitate the specific role of fish oil and/or fatty acids in rainbow trout.

Finally, it seems that dietary fish oil removal was well tolerated in rainbow trout and had no major effects on liver metabolism. Intestine was more sensitive to reduction in fish oil level. Further studies are now in progress to investigate globally the effects of fish oil in rainbow trout liver and intestine using integrative approaches.

\section{Acknowledgements}

SDC was supported by a post-doctoral INRA grant (2003-2005) and NR by a PhD grant INRA-IFREMER (2002-2005). This work was financed by AGENAE french programme (Analyse du GENome des Animaux d'Elevage), CIPA (Comité Interprofessionnel des Produits de l'Aquaculture), OFIMER (Office National Interprofessionnel des Produits de la Mer et de l'Aquaculture), and Aquitaine Region (no. CCRRDT20040308001). We acknowledge M. M. Le Gall, H. Le Delliou, M. Necol, F. Gai, E. Plagnes-Juan, C. Vachot, M. J. Borthaire and L. Larroquet for their excellent technical assistance. We thank F. Terrier, Y. Hontang and F. Sandres for preparation of diets and rearing fish in INRA experimental farm (Donzacq, Landes, France).

\section{References}

Bell JG, McEvoy J, Tocher DR, McGhee F, Campbell PJ and Sargent JR 2001. Replacement of fish oil with rapeseed oil in diets of Atlantic salmon (Salmo salar) affects tissue lipid compositions and hepatocyte fatty acid metabolism. Journal of Nutrition 131, 1535-1543.

Bell JG, Henderson RJ, Tocher DR, McGhee F, Dick JR, Porter A, Smullen RP and Sargent JR 2002. Substituting fish oil with crude palm oil in the diet of Atlantic salmon (Salmo salar) affects muscle fatty acid composition and hepatic fatty acid metabolism. Journal of Nutrition 132, 222-230.

Bell JG, Tocher DR, Henderson RJ, Dick JR and Crampton Vo 2003. Altered fatty acid compositions in Atlantic salmon (Salmo salar) fed diets containing linseed and rapeseed oils can be partially restored by a subsequent fish oil finishing diet. Journal of Nutrition 133, 2793-2801.

Bell JG, Henderson RJ, Tocher DR and Sargent JR 2004. Replacement of dietary fish oil with increasing levels of linseed oil: tailoring flesh fatty acid composition in Atlantic salmon (Salmo salar) using a fish oil finishing diet. Lipids 39, 223-232.

Bergen WG and Mersmann HJ 2005. Comparative aspects of lipid metabolism: impact on contemporary research and use of animal models. Journal of Nutrition 135, 2499-2502.

Bessey OA, Lowry $\mathrm{OH}$ and Brock MJ 1946. Rapid coloric method for determination of alcaline phosphatase in five cubic millimeters of serum. Journal of Biological Chemistry 164, 321-329.

Bourre JM 2005. Dietary omega-3 fatty acids and psychiatry: mood, behaviour, stress, depression, dementia and aging. The Journal of Nutrition, Health \& Aging 9, 31-38.

Bradford MM 1976. A rapid and sensitive method for the quantitation of microgram quantities of protein utilizing the principle of protein-dye binding. Analytical Biochemistry 72, 248-254.

Cahu CL, Zambonino Infante JL, Corraze G and Coves D 2000. Dietary lipid level affects fatty acid composition and hydrolase activities of intestinal brush border membrane in seabass. Fish Physiology and Biochemistry 23, 165-172.

Collins QF, Xiong Y, Lupo EG, Liu JH and Cao W 2006. p38 mitogen-activated protein kinase mediates free fatty acid-induced gluconeogenesis in hepatocytes. Journal of Biological Chemistry 281, 24336-24344.

Cowey C and Walton M 1989. Intermediary metabolism. In Intermediary metabolism (ed. C Cowey and W Walto), pp. 259-329. Academic Press, Amsterdam.

Crane RK, Bogé G and Rigal A 1979. Isolation of brush border membranes in vesicular form from the intestinal spiral valve of the small dogfish (Scyliorhinus canicula). Biochimica Biophysica Acta 554, 264-267.

Dabrowski K and Guderley H 2002. Intermediary metabolism. In Fish nutrition (ed. JE Halver and RW Hardy), pp. 309-365. Academic Press, New York, USA. Dahlqvist A 1970. Assay of intestinal disaccharidase. Enzymologia Biologica et Clinica 11, 52-66.

Dhabbi JM, Mote PL, Wingo J, Tillman JB, Walford RL and Spindler SR 1999. Calories and aging restriction alter gene expression for gluconeogenic, glycolytic and nitrogen-metabolizing enzymes. American Journal of Physiology: Endocrinology and Metabolism 277, E352-E360.

Folch J, Lees M and Stanley GH 1957. A simple method for the isolation and purification of total lipids from animal tissues. Journal of Biological Chemistry 226, 497-509.

Gelineau A, Corraze G, Boujard T, Larroquet L and Kaushik S 2001. Relation between dietary lipid level and voluntary feed intake, growth, nutrient gain, lipid deposition and hepatic lipogenesis in rainbow trout. Reproduction, Nutrition, Develoment 41, 487-503.

Han E and Hickey M 2005. Microarray evaluation of dietary restriction. Journal of Nutrition 135, 1343-1346.

Hemre GI, Mommsen TP and Krogdahl A 2002. Carbohydrates in fish nutrition: effects on growth, glucose metabolism and hepatic enzymes. Aquaculture Nutrition 8, 175-194.

Henderson RJ and Sargent JR 1981. Lipid biosynthesis in rainbow trout, Salmo gairdnerii, fed diets of different lipid contents. Comparative Biochemistry and Physiology 69C, 31-37.

lijima N, Tanaka S and Ota Y 1998. Purification and characterization of bile salt-activated lipase from the hepatopancreas of the red sea bream, Pagrus major. Fish Physiology and Biochemistry 18, 59-69. 
Ismail HM 2005. The role of omega-3 fatty acids in cardiac protection: an overview. Frontiers in Biosciences 10, 1079-1088.

Jones HE, Harwood JL, Bowen ID and Griffiths G 1992. Lipid composition of subcellular membranes from larvae and prepupae of Drosophila melanogaster. Lipids 27, 984-987.

Jordal AO, Torstensen BE, Tsoi S, Tocher DR, Lall SP and Douglas SE 2005. Dietary rapeseed oil affects the expression of genes involved in hepatic lipid metabolism in Atlantic salmon (Salmo salar). Journal of Nutrition 135, 2355-2361.

Jump DP, Botolin D, Wang Y, Xu J, Christian B and Demeure 02005. Fatty acid regulation of hepatic gene transcription. Journal of Nutrition 135 , 2503-2506.

Kirchner S, Kaushik S and Panserat S 2003a. Effect of partial substitution of dietary protein by a single gluconeogenic dispensable amino acid on hepatic glucose metabolism in rainbow trout (Oncorhynchus mykiss). Comparative Biochemistry and Physiology Part A 134/2, 337-347.

Kirchner S, Kaushik S and Panserat S 2003b. Low protein intake is associated with reduced hepatic gluconeogenic enzyme expression in rainbow trout (Oncorhynchus mykiss). Journal of Nutrition 133, 2561-2564.

Kobayashi A, Jiang LL and Hashimoto T 1996. Two mitochondrial 3hydroxyacyl-CoA dehydrogenase in bovine liver. Journal of Biochemistry 119, 775-782.

Koh H, Lee S, Son B, Lee S, Ryoo Z, Chang K, Park J, Park D, Song B, Veech R, Song $\mathrm{H}$ and Huh T 2004. Cytosolic NADP+-dependent isocitrate dehydrogenase plays a key role in lipid metabolism. Journal of Biological Chemistry 279, 39968-39974.

Lam T, Carpentier A, Lewis G, van de Werve G, Fantus I and Giacca A 2003. Mechanisms of the free fatty acid-induced increase in hepatic glucose production. American Journal of Physiology: Endocrinology and Metabolism 284, 863-873.

Mambrini M, Vachot C and Kaushik S 1998. The effects of including soy protein concentrates in diets fed to rainbow trout on the activities of trans-deaminating enzymes. Reproduction, Nutrition, Development 38, 199.

Maroux S, Louvard D and Baratti J 1973. The aminopeptidase from hogintestinal brush border. Biochimica Biophysica Acta 321, 282-295.

Meister A, Tate SS and Griffith OW 1981. $\gamma$-glutamyl transpeptidase. In Methods in enzymology (ed. WB Jakoby), pp. 237-253. Academic Press Inc., New York, USA.

Meton I, Mediavilla D, Caseras A, Cantó E, Fernández F and Baanant IV 1999. Effect of diet composition and ration size on key enzyme activities of glycolysis-gluconeogenesis, the pentose phosphate pathway and amino acid metabolism in liver of gilthead sea bream (Sparus aurata). British Journal of Nutrition 82, 223-232.

National Research Council 1993. Nutrient requirements of fish. National Academy Press, Washington, DC, USA.

Naylor RL, Goldberg RJ, Primavera JH, Kautsky N, Beveridge MCM, Clay J, Folke C, Libchenko J, Mooney $\mathrm{H}$ and Troell M 2000. Effect of aquaculture on world fish supplies. Nature 405, 1017-1024.

Nettleton J and Katz R 2005. n-3 polyunsaturated fatty acids in type 2 diabetes: a review. Journal of the American Dietetic Association 105, 428-440.

New MB and Wijkstroem UN 2002. Use of fishmeal and fish oil in aquafeeds. Further thoughts on the fishmeal trap FAO Fisheries circular no. 975. Food and Agriculture Organization, Rome.

Olsvik P, Lie K, Jordal A, Nilsen T and Hordvik I 2005. Evaluation of potential reference genes in real time RT-PCR studies of Atlantic salmon. BMC Molecular Biology 17, 6-21.

Panserat $S$, Médale F, Brèque J, Plagnes-Juan E and Kaushik S 2000. Lack of significant long-term effect of dietary carbohydrates on glucose-6-phosphatase expression in liver of rainbow trout (Oncorhynchus mykiss). Journal of Nutritional Biochemistry 11, 22-29.

Panserat S, Plagnes-Juan E, Breque J and Kaushik S 2001a. Hepatic phosphoenolpyruvate carboxykinase gene expression is not repressed by dietary carbohydrates in rainbow trout (Oncorhynchus mykiss). Journal of experimental Biology 204, 359-365.

Panserat S, Plagnes-Juan E and Kaushik S 2001b. Nutritional regulation and tissue specificity of gene expression for key proteins involved in hepatic glucose metabolism in rainbow trout (Oncorhynchus mykiss). Journal of Experimental Biology 204, 2351-2360.

Panserat S, Perrin A and Kaushik S 2002. High dietary lipids induce liver glucose-6-phosphatase expression in rainbow trout (Oncorhynchus mykiss). Journal of Nutrition 132, 137-141.

Pfaffl MW 2001. A new mathematical model for relative quantification in realtime RT-PCR. Nucleic Acids Research 29, 2002-2007.

Pfaffl MW, Horgan GW and Dempfle L 2002. Relative expression software tool $\left(\mathrm{REST}^{\circ}\right)$ for group-wise comparison and statistical analysis of relative expression results in real-time PCR. Nucleic Acids Research 30, 9-36.

Pilkis SJ and Granner DK 1992. Molecular physiology of the regulation of hepatic gluconeogenesis and glycolysis. Annual Review of Physiology 54, 885-909.

Reddy JK and Hashimoto T 2001. Peroxysomal $\beta$-oxydation and peroxysomal proliferator-activated receptor $\alpha$ : an adaptative metabolic system. Annual Review of Nutrition 21, 193-230.

Richard N, Kaushik S, Larroquet L, Panserat S and Corraze G 2006. Replacing dietary fish oil by vegetable oils has little effects on lipogenesis, lipid transport and tissue lipid uptake in rainbow trout. British Journal of Nutrition 96, 299-309.

Rollin X, Médale F, Gutieres S, Blanc D and Kaushik S 2003. Short- and longterm nutritional modulation of acetyl-CoA carboxylase activity in selected tissues of rainbow trout (0. mykiss). British Journal of Nutrition 89, 803-810.

Salati LM and Amir-Ahmady B 2001. Dietary regulation of expression of glucose-6-phosphate dehydrogenase. Annual Review of Nutrition 21, $121-140$.

Sampath $\mathrm{H}$ and Ntambi JM 2005. Polyunsaturated fatty acid regulation of genes in lipid metabolism. Annual review of Nutrition 25, 317-340.

Sargent S, Tocher DR and Bell JG 2002. The lipids. In Fish nutrition (ed. JE Halver and RW Hardy), pp. 182-246. Academic Press, San Diego, California, USA.

Shantha NC and Ackman RG 1990. Nervonic acid v. tricosanoic acid as internal standards in quantitative gas chromatographic analyses of fish oil longer-chain $\mathrm{n}-3$ polyunsaturated fatty acid methyl esters. Journal of Chromatography B: Analytical Technologies in the Biomedical and Life Sciences 533, 1-10.

Spinder SR 2001. calorie restriction enhances the expression of key metabolic enzymes associated with protein renewal during aging. Annals of the New York Academy of Sciences 928, 296-304.

Statistical Packages for the Social Sciences 1999. Systat 9 software products. SPSS Inc., Chicago, IL, USA.

Stubhaug I, Tocher DR, Bell JG, Dick JR and Torstensen BE 2005. Fatty acid metabolism in Atlantic salmon (Salmo salar) hepatocytes and influence of vegetable oil. Biochimica Biophysica Acta 1734, 277-288.

Sul $H$ and Wang D 1998. Nutritional and hormonal regulation of enzymes in fat synthesis. Annual Review of Nutrition 18, 331-351.

Tapia-Salazar M, Bureau W, Panserat S, Corraze G and Bureau D 2006. Effect of DHA supplementation on digestible starch utilization by rainbow trout. British Journal of Nutrition 95, 1-12.

Thivend P, Mercier C and Guilbot A 1972. Determination of starch with glucoamylase. In Methods in carbohydrate chemistry (ed. RL Whistler and JN Bemiller), pp. 100-105. Academic Press, New York, USA.

Tocher DR, Bell JG, MacGlaughlin P, McGhee F and Dick JR 2001. Hepatocyte fatty acid desaturation and polyunsaturated fatty acomoposition of liver in salmonids: effects of dietary vegetable oil. Comparative Biochemistry and Physiology 130B, 257-270.

Tocher DR, Bell JG, McGhee F, Dick JR and Fonseca-Madrigal J 2003. Effects of dietary lipid level and vegetable oil on fatty acid metabolism in Atlantic salmon (Salmo salar) over the entire production cycle. Fish Physiology and Biochemistry 29, 193-209.

Tocher DR, Fonseca-Madrigal J, Dick JR, Ng WK, Bell JG and Campbell PJ 2004. Effects of diets containing crude palm oil and water temperature on fatty acid desaturation and oxidation in hepatocytes and intestinal enterocytes in rainbow trout (Oncorhynchus mykiss). Comparative Biochemistry and Physiology 137B, 49-63. 
Ducasse-Cabanot, Zambonino-Infante, Richard, Medale, Corraze, Mambrini, Robin, Cahu, Kaushik and Panserat

Tong L 2005. Acetyl-coenzyme A carboxylase: crucial metabolic enzyme and attractive target for drug discovery. Cellular and Molecular Life Sciences 62, 1784-1803.

Torstensen BE, Lie 0 and Froyland L 2000. Lipid metabolism and tissue composition in Atlantic salmon (Salmo salar L) - effects of capelin oil, palm oil, and oleic acid-enriched sunflower oil as dietary lipid sources. Lipids 35, 653-664.
Torstensen BE, Bell JG, Rosenlund G, Henderson RJ, Graff IE, Tocher DR, Lie $O$ and Sargent JR 2005. Tailoring of Atlantic salmon (Salmo salar) flesh lipid composition and sensory quality by replacing fish oil with a vegetable oil blend. Journal of Agricultural and Food Chemistry 53, 10166-10178.

Van Schaftingen E and Gerin I 2002. The glucose-6-phosphatase system. Biochemical Journal 15, 513-532. 